\title{
POLISH CONTRIBUTION TO THE DEVELOPMENT OF VIEWS ON HORSE RIDING AS A FORM OF THERAPY - A BRIEF HISTORICAL RETROSPECTION
}

\author{
Renata Urban \\ University of Szczecin, Faculty of Physical Culture and Health Promotion, Poland \\ Address for correspondence: \\ Renata Urban \\ University of Szczecin, Faculty of Physical Culture and Health Promotion \\ Al. Piastów 40b, building 6, 71-065 Szczecin, Poland \\ E-mail: renata.urban@usz.edu.pl
}

\begin{abstract}
Ahstract Since ancient times, man has ridden horses. Ancient Greeks and Romans, who did so mostly for utilitarian purposes, also found that horse riding was the source of rider's health, recommending equestrianism to men and women of different ages as an exercise that helped preserve a healthy body.

Poles, a nation whose history was always linked in a rather exceptional way with horses and horsemanship, realized quite early, at the beginning of the $17^{\text {th }}$ century, that horse riding offered a variety of applications and could be used as a tool to improve human fitness and physical condition. Views of Polish hippologists such as Krzysztof Moniwid Dorohostajski and Marian HuttenCzapski on health-related benefits of equestrianism gained popularity not only in Poland but also abroad. At the beginning of the $20^{\text {th }}$ century, their opinions were endorsed by a Polish doctor, Władysław Hojnacki, who campaigned for horse riding to be used as therapy. After WW2, a distinguished Polish orthopedist and physiotherapist, Professor Marian Weiss introduced an innovative hippotherapeutic program at the Medical Center for Rehabilitation of the Locomotive Organs in Konstancin near Warsaw, finding many followers who helped hippotherapy to develop. Research confirmed that horse riding was indeed an effective form of therapy and this soon led to the establishment of the Polish Hippotherapeutic Society, organization of conferences and seminars providing a platform where views and research results could be exchanged, and starting a number of equestrian facilities across the country that popularized hippotherapy in Poland.
\end{abstract}

Key Words horse, horse riding, hippotherapy, Poland

\section{Introduction}

People have ridden horses since ancient times. In the beginning, the horse played a primarily utilitarian role, helping the rider travel over long distances or transport goods. It was always a status symbol, a visible manifestation of importance and wealth of its owner. Later on, parallel to its original function, new ways of using the horse evolved - riding for pleasure, recreation, sport, or therapy. Generally speaking, each of these functions followed its own path but often - for the first time in the Antiquity, then in the $20^{\text {th }}$ and $21^{\text {st }}$ centuries - their elements intertwined producing hippotherapy, i.e. horse riding for therapeutic purposes and the equestrian sport for the disabled, as well as the 
equestrian 'community', or 'family', a group of people for whom interaction with the horse and horse riding have become part of their way of life.

\section{Views of ancient physicians and philosophers on the significance of horse riding}

The first symptoms of interest in the advantages of horse riding and its positive influence on the rider maintaining, recovering and improving good health appeared as early as the Antiquity. Theories to that effect were put forth in several medical treatises by Hippocrates (about 460-370 B.C.), a Greek physician and father of modern medicine, whose name in Greek meant 'he who controls the horse' (Wyżnikiewicz-Nawracała, 2002). Other ancient philosophers, for example Plato (427-347 B.C.), shared Hippocrates' sentiment, encouraging adolescents, both male and female, to take up horse riding as a form of exercise: (...) and women, too, should practice, in much the same manner. I would not fear to say this to you - one must not treat horse riding and gymnastics as occupations appropriate for men but, for some reason, inappropriate for women (Kunicki, 2002). General references to the topic can also be found in the works of Xenophon (430-355 B.C.), for example The Art of Horsemanship' and 'Hipparchius, although it is rather difficult to find in them more precise recommendations of the author and his contemporaries on the subject of therapeutic application of horse riding. Theories on the benefits of physical exercise, horse riding included, for human well-being and health were also endorsed and developed by one of the most eminent Roman physicians, a Greek by birth, Claudius Galenus (about 130-200 A.D.) (Lyons, Petrucelli, 1996).

\section{Revival of interest in horse piding among physicians of modern times}

Drawing on the experience of renowned members of the medical profession of the ancient world whose heritage in the form of numerous medical writings remained accessible in Italian libraries, many physicians of the modern era picked up and elaborated on the topic, arguing that horse riding could indeed treat a variety of ailments and improve human health and fitness.

In the $16^{\text {th }}$ century, an Italian physician, Girolamo Mercuriale (1530-1606) studied the subject, publishing his findings in De Arte Gymnastika (1569). In his medical practice he applied his own therapeutic methods and laid foundations for modern physiotherapy. Others that followed suit were Thomas Sydenham (1624-1689), an English doctor, who published Tractatus de podagra et hydrope (1683), Francis Fuller (1670-1706), an English medical writer, who printed Medicina Gymnastica (1705), and Friedrich Busch (1844-1916), a German physician, who propagated his theories in Allgemeinen Orthopadie, Gymnastik und Massage (1882) (Wyżnikiewicz-Nawracała, 2002).

\section{Views of Polish hippologists and physicians on the impact of horse piding on health and fitness of young people}

To a substantial degree horse riding as a form of therapy was popularized by Polish authors, who argued that time spent in the saddle contributed greatly to the rider remaining in good health or, when necessary, recovering from illness. Polish culture, customs, and everyday life had always been rather uniquely intertwined with horses and horsemanship, and horse riding was seen as a particularly beneficial way of exercise. Encouraged to take to the saddle were people of all ages, even those decidedly past their prime. Longevity, which by no means was a widespread phenomenon in the $16^{\text {th }}$ or $17^{\text {th }}$ centuries, (for example, Mikołaj Odrowąz Pieniążek lived to be over eighty, or Helena Ogińska died at ninety), was attributed to the horsemanship skills of the long-living individuals and their regular engagement in horse riding. It was a generally held belief that the movement of the horse's back 
under saddle improved the rider's blood circulation and muscular performance, a theory that came to be confirmed by scientific research several hundred years later. This deeply-rooted popular conviction that horse riding was an excellent health enhancer was also reflected in Polish folklore and language: Good horse - healthy rider, or A good horse is half of one's health (Hutten-Czapski, 1985; Sawicka, 2002).

A systematized body of knowledge on the subject was first promulgated in Poland by Krzysztof Moniwid Dorohostajski, Grand Marshall of Lithuania and hippologist. Having studied the matter abroad and travelled intensely, especially to and around Italy, he published the work of his lifetime in 1603. The book titled Hippica a Much Needed Treatise on Horses and a Joyful Reading for Men of the Sword, Published for Clarity of the Subject was based on years of Dorohostajski's extensive experience and practical research. For more than 250 years to come it remained the most exhaustive Polish publication on all aspects of the use of the horse, emphasizing healthrelated advantages of horse riding (Dorohostajski, 2015). It was not until 1874 that Duke Marian Hutten-Czapski, renowned hippologist, bee-keeper, holder of a doctoral degree in law, and participant in the January Uprising of 1863, published in Poznan a three-volume Common History of the Horse, which he dedicated to 'the young generation' and supplemented with An Atlas for the Common History of the Horse, Presenting in LXXV Charts Types of Horses from Various Countries and Everything that Has Always Concerned the Subject. In it Czapski bore out and expanded the views expressed by Dorohostajski and other authors, foreigners included, stressing positive aspects of horse riding and benefits produced by practicing horsemanship. He wrote: At the time, riding in the saddle was regarded to be an unfailing means of maintaining or recovering good health because, it was believed, the movements of the rider's body which the horse stimulated improved blood circulation. People also thought that the trot did good to infirm individuals, while the walk helped hypochondriacs (Hutten-Czapski, 1985).

The second half of the $19^{\text {th }}$ century saw a change in perception of horse riding and the role it played. It was no longer considered a mere necessity stemming from the need to travel, but gradually became more of a pleasant experience that the communing with a friendly mount and the trail invariably produced. A number of new sports emerged, for example cycling, rowing, fencing, skiing, skating, and, not surprisingly, horse riding. Other sports gained in popularity. Sports clubs and sports societies sprang into life, promoting sporty competition. Horse riding found new enthusiasts, not only in the countryside, where it had always been a natural form of physical activity, but also in towns, where it assumed more organized forms. 'Tattersalls' were set up across the country. Patterned after the original English race horse auctioneers, these were businesses that bought and sold horses but, most importantly, thought horsemanship to members of the general public. The Sokół Gymnastic Society, established in Poland in 1867, started several horse riding clubs where young people in cities and towns took riding lessons. By the end of the century, young riders had developed their own unique lifestyle characterized by physical activity, courage, and pursuit of a variety of interests, which, especially for female riders at the time, required much determination (Urban, 2003).

Involvement of women in the popularization of horse riding in general, and its therapeutic qualities in particular, became part of a broader emancipation movement of the turn of the $19^{\text {th }}$ and $20^{\text {th }}$ centuries. Its propagator in Poland was Maria Wodzińska (born in 1868), one of many female riders at the time, but the only one who did not hesitate to join the public discussion on the benefits of horse riding. Contrary to a widespread opinion that it was inappropriate for women to practice certain sports and that their physical activity should therefore be restricted, she encouraged women to learn to ride, arguing that horse riding exerted a beneficial influence on the body and had a variety of other advantages (Urban, 2000). 
Maria Wodzińska proved to be a talented writer, too. She would publish newspaper articles about horse riding that were as charming as they were interesting and professional. In 1893 The Amazon was printed, the first and, for many years, the only Polish horse riding manual for female riders, in which the author elaborated on female health and the impact of the horse on maintaining and improving it. (...) In England, France, and almost everywhere else, women tend to attain true perfection in this respect [as riders]. In Poland, it was not long ago that people thought it [horse riding] eccentric and would point the finger at ladies in the saddle. (...) Even today one can hear outraged voices criticizing women who decide to mount up and, apparently, run the risk of a voluntary death. Some critics even claim that of all dangers that a human being has to face in the course of their life, finding themselves in the saddle is by far the gravest! If you, ladies, only knew how horse riding, this most noble pastime, can revitalize the feeble body, the perturbed mind, and even the spirit, perhaps you would take to it more readily and encourage you children to do so as early as possible. In the past people wrongly believed that horse riding could ruin the health of not only married women, but maidens as well. Even today there are doctors who rigorously forbid their female patients to ride horses. Fortunately, there are many others who recommend it as an exercise that is very hygienic, if not downright therapeutic, since the movement of the rider's muscles in faster gaits bears a striking resemblance to massage, so popular today, oftentimes exceeding it in effectiveness (Wodzińska, 1893).

Wodzińska's views, sound as they were, needed time to earn recognition among members of the general public. Although more horseman and horsewomen were seen taking pleasure rides in city parks and gardens, and the popularity of tattersalls and Sokół Gymnastic Society's riding schools rose, these were more the effects of changes in the lifestyle of the younger generation and sports becoming a new fashion than signs of true understanding of the therapeutic qualities of horse riding. Despite all her practical experience, Wodzińska was not a doctor or hygienist. Moreover, she was a women, which back then played a colossal role.

Yet the endeavors of the author of 'The Amazon' do not go to waste, especially when the public debate on health-related advantages of horse riding was joined by Władysław Hojnacki (1869-1931), a doctor and gynecologist in Lviv. He was generally esteemed not only for his extensive medical qualifications but also practical experience. For many years Hojnacki was an active member of the Sokół Gymnastic Society in Lviv, which had run a riding club since 1894 (National Archives, Krakow). This gave him a first-hand opportunity to observe changes that occurred in the body of the rider who practiced horse riding regularly. Hojnacki took part in the International Congress of Physical Education in Paris, France, (March 17-20, 1913), wrote books and papers on sports and healthy lifestyle, and pioneered the notion of hygiene. Also, he was an ardent propagator of physical activity, especially among women and girls who, in a misguided effort to remain in good health, often chose to stay indoors without fresh air (Kozubal, 2017).

In his regular lectures on the impact of sports on human health, Doctor Hojnacki talked much more about the need for physical activity in women than men because he thought that one of the most (...) neglected aspects is the balance between the mental and physical development of adolescent boys and girls, (...) where in truth every single, more vigorous, physical effort from a student must be explained, and then begged or clamored for. No wonder that twigs so bent, as it were, produce crooked trees - in other words, young people of today will most certainly turn into adults who won't not know how to exercise, nor will they exhibit any appreciation of the need for physical activity (Hojnacki, 1905a). Hojnacki was determined to convince his contemporaries, especially the young ones, that practicing sports could prove beneficial to their health, and that it was an attractive and fashionable undertaking. Luckily, his efforts to that end were facilitated by fast-growing sports competition and a growing number of sports 
events, for instance the Olympic games. Hojnacki believed that horse riding (...) is a sport that ideally suits women, a beautiful sport, good for the physique and the morale, fit even for the more frail-bodied and delicate ones, and those who are recovering from illness; many doctors find it an effective means of therapy for their female patients (Hojnacki, 1905a).

On April 15, 1905, on request of the Polish Society for Recreation of the Working Classes and the Young, Hojnacki gave a talk on the subject of horse riding as a sport and therapy. He started out by outlining the history of the horse under saddle, from the most remote times to his, and explained how riding a horse enhances human health. There are many contributing factors, the first one being the movement of the body and the limbs of the rider, movement, mind you, which can range from passive shocks experienced by the rider on a quiet and composed horse in a slow gait, to increasingly intense motions, strains, and jolts that the rider must sustain or absorb, as the horse's speed picks up and his temperament becomes more palpable (Hojnacki, 1905b).

Hojnacki argued that the pain the rider experiences in the thighs, the hips, the lower back, and other parts of the body, admittedly uncomfortable, should be seen as a positive symptom of muscular effort and, as such, a very beneficial experience. He pointed out, quoting physicians from other countries as well, that the rider's pulmonary system undergoes positive changes - breath deepens substantially and, in time, lung capacity increases. He stressed that horse riding demonstrated another invaluable characteristic - riding in parks and across country, which, according to Hojnacki, should ideally be embarked upon in the early morning, allowed (...) one to delight in the beauty of nature at the break of the day (...), which is an experience that exerts a positive impact on the entire nervous system, sets the right mood for the rest of the day, whets the appetite, and improves efficiency of whatever labors the rider intends to perform during the day (Hojnacki, 1905b). He remarked that horse riding played an important social role, too, by providing an excellent opportunity for equestrians to make new acquaintances. It helped them stay in good mental health, energized their bodies, made them more courageous and able to react quickly to the changing surroundings, and, at the same time, thought them gentleness, patience, and affection towards a living animal.

At the beginning of the $20^{\text {th }}$ century, continued Hojnacki, horse riding found a variety of health-related applications: for hygienic reasons it was recommended to people who performed work of cerebral nature; as recuperation enhancer, it was recommended to convalescents weakened by illness; as therapy, it was recommended to patients suffering from hysteria, neurasthenia, hypochondria, muscular atrophy, anemia, chlorosis, lack of appetite, digestive problems, uric acid diathesis, or obesity; and, prophylactically, against tuberculosis (that last correlation was identified through research and observation of French cavalrymen and infantry). In spite of the advantages he enumerated, Hojnacki warned novice equestrians against incompetent use of the horse, misjudgment of their own riding skills, and inability to choose the right horse for the rider's needs. He advised caution, i.e. medical consultations and assistance of an experienced riding coach. All in all, however, as an equestrian example to follow he held up the English high society, in whose opinion horse riding was (...) the first dream of a virgin and the last joy of an old man (Hojnacki, 1905b).

The inter-war years, i.e. the period between 1918 and 1939 spanning the two world wars, brought with it revolutionary changes in the riding seat, especially by female riders, and in the riding technique (Pruski, 1978, Urban, 2003). Research into the influence of horse riding on human health, both in Poland and abroad, continued. In 1930, upon a thorough analysis of available literature, a German country doctor by the name of Max Senator published a book titled Health-Related Quality of Horse Riding. In its final part, the author put a very sensible 
sentence: A true doctor must understand the art of dosing, that is to say, he must know the exact measures of his medications and auxiliary substances. This constatation applies also to horse riding (Wyżnikiewicz-Nawracała, 2001).

\section{Horse piding as a form of locomotor rehabilitation}

Experience gathered over the years came in very useful in the 1940s and 1950s, when poliomyelitis, a disease against which no one had a vaccine yet, spread across Europe (an epidemic struck Poland in 1951, an recurred repeatedly in the following years) (Kwolek, 2014). The horse proved to be an effective weapon in fighting the disease, as was illustrated by the somewhat spectacular story of a Danish rider, Lis Hartel, who suffered from the spinal form of that disease, manifesting itself in flaccid paralysis of the lower limbs. Horse riding prescribed to Hartel as part of therapy produced effects that were positive enough to allow the young equestrian to return to active riding and win two silver medals in dressage at two consecutive Olympic games, in 1952 in Helsinki, and in 1956 in Melbourne (when horse riding events held in Stockholm). The achievements of the young Dane helped to propagate a general understanding that horse under saddle can be successfully used in therapy (Porażenie dziecięce, 1994; Sawaryn, 2008; Szabert, 2012).

It was in the 1950s that horse riding was introduced into the program of broadly understood locomotor rehabilitation. A number of organizations and societies supporting therapeutic equestrianism were set up, initially in Great Britain and Canada, later on in the USA and other countries. Finally, in 1976 in Basel, Switzerland, was held the first international congress on the treatment of various diseases (not only locomotor conditions) by means of horse riding (Szabert, 2012).

In post-WW2 Poland, equestrianism was not very popular, partly due to the politics of the new, communist regime which thought it a relic of the 'aristocratic' Second Republic. It was however much appreciated as a means of therapy. At first, horses were applied in therapy of visually impaired children at a medical center in Łódź by Doctor Buczkowski. Soon the idea was transferred to a medical facility in Konstancin, near Warsaw, which ran rehabilitation programs for patients with locomotive problems. In 1962, Professor Marian Weiss, head of the facility, introduced hippotherapy (from Greek 'hippos' - horse, and 'therapae' - therapy), an innovative solution at the time, to rehabilitate patients with orthopedic conditions, such as amputations or inborn limb reduction defects, valgus knees and hips, scoliosis, etc, neurological conditions (myelomeningocele, multiple sclerosis, poliomyelitis, etc), and problems of social and mental nature. The medical facility in Konstancin became famous for its hippotherapy programs and for almost twenty years to come remained the only Polish medical center offering that type of treatment (Schweitzer-Wirska, 2006; Polańska, 2003; Jandziś, 2014).

Despite evidently positive effects of hippotherapy on patients suffering from a variety of ailments, it proved difficult and time-consuming for the Polish medical community to embrace the concept of the horse being a generally acceptable rehabilitative instrument. In 1985, in Swoszowice near Kraków, on the initiative of Professor Stanisław Grochmala and Doctor Irena Solecka, horses from the local riding club 'Krakus' came to be routinely used to treat children from across the country that had been qualified for the therapy by doctors at the Regional Mother and Child Medical Center in Krakow. In their opinion (...) the horse is a stimulus which speeds up treatment. The overall physical condition, coordination of body movements, and balance of our child patients improve dramatically. Their mental disposition is much better, too (Pazdyk, 1988, Skorska, 1987). 
A growing interest in hippotherapy called for increasing numbers of hippotherapists to be trained, which, as a result, led to the establishment new hippotherapy facilities. Equine-assisted therapy finally became recognized and appreciated by researchers and academics, but, most importantly, members of the medical world, who praised the benefits of this kind of approach to treatment. The then Chief Physician at the Rehabilitation Department of the City Hospital in Rzeszów, doctor Andrzej Kwolek remarked that (...) the rhythm of the horse's movements (...) engaged in a natural way all the muscles, which, in patients with paralysis, was of paramount importance. (...) Contact with a friendly animal thought the children courage and faith in their own abilities (Zaborniak, 2007; Przyszlak, Zaborniak, 2006). In 1992, in collaboration with the 'Zabajka' Horse Riding Club and as part of its organizational structure, the Rehabilitation Department started a hippotherapy section, one of the first few horse riding sections of this kind in the country.

The popularity of therapeutic horse riding continued to grow - so much so that a training course organized in 1987 in Krakow for equestrian therapists, trainers, and instructors was attended by over 50 participants from all over Poland, leading, in the subsequent years, to the foundation of new hippotherapy centers and new hippotherapy sections at horse riding clubs. Their operation was coordinated by the Polish Hippotherapeutic Society (or PHS) in Krakow, set up in 1992, which created a platform for cooperation between experts in a number of hippotherapysupporting fields - doctors, physiotherapists, psychologists, learning coaches, horse riding instructors, horse breeders, etc. The number of riding facilities offering hippotherapy under the auspices of the PHS has been going every year (there were 21 in 2002 and 45 in 2018), an effect, no doubt, of several factors, such as the Hippotherapy for Disabled Children Foundation starting in Krakow, organization of academic conferences on the subject (the first one in 1992 called 'Hippotherapy - Theory, Practice, Potential'), and regular publication since 2006 of an academic quarterly ‘The Hippotherapy Review’ (Blichiewicz, Jackowski, Zrubek, 1988; Witkowska, 2006).

\section{Conclusions}

For centuries, horse riding was very popular in Poland. The horse was a prominent element of everyday life of all classes of the Polish society of yore. In time, it became an inseparable, revered and admired, part of national tradition and pride, and the greatest love of its owner. It was always seen as a reliable and loyal companion. Cavalrymen of the Second Republic used to say: Before a maiden, the horse only. After a brief period of communist 'disgrace', horse riding has been regaining its popularity with much vigor - it is now a form of recreation, an effective method of therapy, and a very important element of lifestyle of those who long to return to nature.

\section{References}

Archiwum Państwowe w Krakowie, Starostwo Grodzkie Krakowskie, Statut Towarzystwa Gimnastycznego "Sokół” we Lwowie, sygn. 216.

Blichiewicz, K., Jackowski, M., Zrubek, B. (1988). Hipoterapia. Koń Polski, 4, 32-33.

Dorohostajski, K.M. (1603). Hippica to jest o koniach księgi potrzebna i krotochwilna młodości zabawa ku pożytkowi ludzi rycerskich na jasność wydana. Kraków (reprint - Warszawa 2015).

Hojnacki, W. (1905a). Kobieta a sport. In: W. Hojnacki, Z dziedziny sportu. Lwów-Warszawa: Nakład Księgarni Polskiej B. Połonieckiego. Hojnacki, W. (1905b). Sport jazdy konnej. In: W. Hojnacki, Z dziedziny sportu. Lwów-Warszawa: Nakład Księgarni Polskiej B. Połonieckiego.

Hutten-Czapski, M. (1874). Historia powszechna konia, t. II. Poznań (reprint - Warszawa 1985). 
Jandziś, S. (2014). Z dziejów rehabilitacji medycznej i sportu osób niepełnosprawnych w Polsce (1944-1989). Rzeszów: Wydawnictwo Uniwersytetu Rzeszowskiego.

Kozubal, A. (2017). Problematyka kultury fizycznej współczesnej szkoły a postulaty Władysława Hojnackiego z początku XX wieku. Polski Przegląd Nauk o Zdrowiu, 1 (50).

Kunicki, B.J. (2002). Kultura fizyczna kobiet w antycznej Grecji. In: T. Jurek (ed.), Studia z dziejów kultury fizycznej. Gorzów Wielkopolski.

Kwolek, A. (2014). Historia rehabilitacji neurologicznej w Polsce. In: S. Jandziś, A. Kwolek, Rozwój rehabilitacji w wybranych specjalnościach medycznych w Polsce. Rzeszów: Wydawnictwo Uniwersytetu Rzeszowskiego.

Lyons, A.S., Petrucelli, R.J. (1996). Ilustrowana Encyklopedia Medycyny. Warszawa: Wydawnictwo Penta.

Pazdyk, G. (1988). Wierzchowcem po nadzieję... Wiadomości Sportowe, 21, 6.

Polańska, H. (2003). Dama w siodle. Warszawa: Muzeum Łowiectwa i Jeździectwa.

Porażenie dziecięce - Polska podejmuje walkę z nim (1994) In: Kronika medycyny. Warszawa: Wydawnictwo Marian B. Michalik.

Pruski, W. (1978). Amazonki polskie dawnych i nowszych czasów. Koń Polski, 3, 49.

Przyszlak, O., Zaborniak, S. (2006). Z działalności Ludowego Klubu Jeździeckiego „Zabajka” Głogów Małopolski. In: L. Nowak (ed.), Z najnowszej historii kultury fizycznej Polski i Polonii. Gorzów Wielkopolski: Polskie Towarzystwo Naukowe Kultury Fizycznej, Oddział Gorzów Wlkp.

Sawaryn, D. (2008). Właściwości konia i mechanizm oddziaływania terapeutycznego. Fizjoterapia, 1, 104.

Sawicka, Z. (2002). Koń w życiu szlachty w XVI-XVIII w. Toruń: Wydawnictwo Adam Marszałek.

Schweitzer-Wirska, Z. (2006). Między grzywą a ogonem. Warszawa: Studio Ten.

Skorska, K. (1987). Trzeba pilnować i dziecka, i konia, i ... rodziców. itd, 24, 18-19.

Szabert, A. (2012). Koń - terapeuta i przyjaciel. Wychowanie Fizyczne i Zdrowotne, 11, 27.

Urban, R. (2000). Prekursorki sportu jeździeckiego w Polsce. In: Z. Wyżnikiewicz-Kopp (ed.), Kobieta na przełomie wieków. Gdańsk: AWFiS Gdańsk.

Urban, R. (2003). Rozwój sportu jeździeckiego w Polsce w latach 1918-1939 (unpublished doctoral thesis). Poznań: AWF Poznań.

Witkowska, M. (2006). Początki hipoterapii w Polsce i na świecie. Przegląd Hipoterapeutyczny, 3, 4.

Wodzińska, M. (1893). Amazonka. Podręcznik jazdy konnej dla dam. Warszawa: Towarzystwo Wyścigów Konnych w Królestwie Polskim.

Wyżnikiewicz-Nawracała, A. (2001). Jeździectwo w terapii, rekreacji i sporcie osób niepełnosprawnych. Gdańsk: Wydawnictwo AWFiS Gdańsk

Wyżnikiewicz-Nawracała, A. (2002). Jeździectwo w rozwoju motorycznym i psychospołecznym osób niepełnosprawnych. Gdańsk: Wydawnictwo AWFiS Gdańsk.

Zaborniak, S. (ed.) (2007). Z dziejów kultury fizycznej w gminie Głogów Małopolski (1978-2006). Głogów Małopolski: Wydawnictwo Uniwersytetu Rzeszowskiego.

Cite this article aS: Urban, R. (2018). Polish Contribution to the Development of Views on Horse Riding as a Form of Therapy a Brief Historical Retrospection. Central European Journal of Sport Sciences and Medicine, 3 (23), 17-24. DOI: 10.18276/ cej.2018.3-02. 